\title{
Research
}

\section{Lobster and Conch Fisheries of Belize: a History of Sequential Exploitation}

\author{
$\underline{\text { Miriam Huitric }}^{1}$
}

\begin{abstract}
This article presents a historical review of the lobster and conch fisheries in Belize, Central America. In terms of yield and value, these are the main wild-caught targets of the national fisheries, a small-scale commercial fishery of around 3000 fishermen. Data were collected during interviews with key informants involved with the fisheries and through literature and archive research. The goal was to study how the fishing industry has responded to environmental signals from these resources and from their ecosystems and ecosystem dynamics. National yields for both lobster and conch have been relatively stable, however, individuals' yields have been declining despite increased effort since the 1980s. This study concludes that the use of fossil fuel-based technology and organizational change, with the establishment of fishermen's cooperatives, have masked environmental signals. This masking, together with economic incentives, has led to the "pathology of resource use." As a symptom of this pathology, four forms of sequential exploitation in these fisheries were identified. A major conclusion is that social resilience may not confer ecological resilience. The development of the cooperatives was needed in order to improve equity in the industry. Before their impacts could be assessed, this organizational change, together with new technology, led to very important and rapid changes in the industry. Together with existing regulations that allow de facto open access to lobster and conch, these changes resulted in a short-term boom that has resulted in the pathology of resource use, with over-capitalization and dependence on maintained yields, regardless of environmental feedback.
\end{abstract}

Key Words: Belize; marine reserves; pathology of resource use; queen conch; sequential exploitation; spiny lobster

\section{INTRODUCTION}

Human activities shape nature and nature shapes the development of human society (van der Leeuw and Team 2000). A fundamental requirement for the sustainability of social and ecological management systems is the ability to respond to environmental feedback (Berkes and Folke 1998b). This paper studies the lobster and conch fisheries in Belize (Fig. 1), Central America, which have shown signs of declining productivity, and how fishers and managers have responded to these declines.

The co-evolutionary character of social-ecological systems reflects the ability for qualitative change to generate and implement innovations and cooperation in the social system for feedback management. In this case study, the decline in productivity of the two fisheries is considered to be environmental feedback. Some of the most sophisticated coevolving systems are common-property institutions that have developed over long periods of time (Ostrom et al. 1999). The institutions controlling lobster fishers in Maine (Acheson 1988) and marine resource tenure systems in Oceania (Ruddle et al. 1992) are good examples. In other cases, such institutions have evolved over a short period of time (in the order of one decade) in response to crisis. Illustrations of this include the Turkish Mediterranean coastal fishery in Alanya (Berkes 1992) or the watershed-based resource management system in western Sweden (Olsson and Folke 2001). In both of these series of examples, there seem to 
Fig. 1. Belize, Central America. The coastline with its offshore barrier reef and atolls, and the coastal towns and fishing villages referred to in the paper.

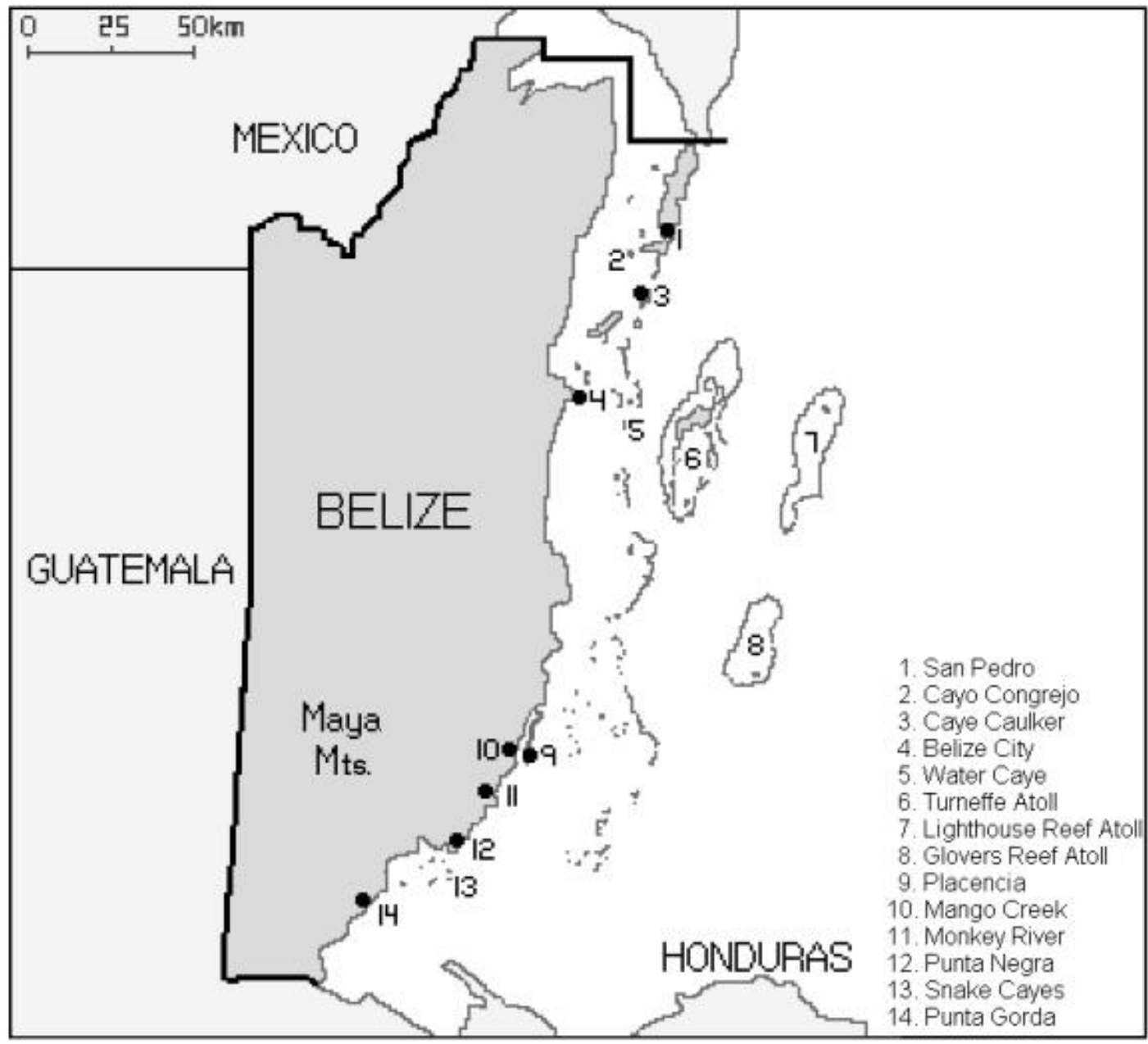

be social mechanisms in place that respond to environmental feedback instead of blocking them out (Berkes and Folke 1998a).

However, managers often neglect environmental feedback or take the capacity of ecosystem production as given. This response and view can arise for many different reasons, including limited monitoring that, in turn, can be due to lack of funding, or political and economic goals. This study focuses on identifying instances and effects of neglecting feedback, and on explaining the root causes of these instances where possible.
Management strategies based on the above views often result in short-term success, which is often reinforced by new technology and capital markets. Such success has caused managers to shift their attention from the original purpose, of managing the resource, to efforts that increase economic or organizational efficiency (Gunderson et al. 1995a). There is a tendency to focus on the yield of desired products by ignoring environmental change and focusing on a simplified set of ecosystem dynamics. Management for optimal production from environments, which are believed to be stable and self-repairable, tends to become alienated from 
ecosystem dynamics, and illiterate when dealing with environmental feedback (Berkes and Folke 2002).

The pattern of environmental management briefly characterized above has been described as the "pathology of natural resource management" (Holling and Meffe 1996). This term has been used for many sectors, in several regions of the world, and over different temporal scales (e.g., Regier and Baskerville 1986, Gunderson et al. 1995a, Redman 1999). In rich regions, the resulting crises have led to spasmodic lurches of learning with expensive actions to reverse the worst of the consequences of past mistakes (Gunderson et al. 1995b). In poor regions, it has resulted in the dislocation of people, impoverishment, and poverty trap (Holling et al. 2002). Ludwig et al. (1993) state that "pathological" resource management techniques have directed fisheries into large-scale fishing concentrated on a few species, and have led to an overcapacity of the fishing fleet and a degradation of important food sources. Evidently, this does not respond to ecosystem dynamics and environmental feedback.

The exploitation pattern of this pathology can be interpreted from a sequential exploitation perspective. Sequential exploitation refers to the movement of resource appropriators to new grounds, as the original ones become unprofitable (Grima and Berkes 1989). In the seas, fishers radiate further from their landing sites as local catches decline. This pattern is described in large-scale industrialized fisheries (Ludwig et al. 1993), and has been described for shrimp aquaculture (Huitric et al. 2002). Sequential exploitation is a result of, and enhances, the pathology of resource use when original grounds are not given respite, through closure or reduced appropriation, but rather new grounds and technologies are relied on to solve scarcity. This is possible through capital investments in technologies to travel further and to intensify extraction. As the theory of the pathology predicts, these investments do not, in fact, solve scarcity problems. Instead they mask scarcity, which postpones having to deal with these problems, as well as extends the scale of the problem. Masking refers to the appearance of abundance following the introduction of these investments, thereby disguising the scarcity that drove the increased investments.

Both lobster and conch are fished throughout the Caribbean with varying degrees of mechanization
(Joyce 1997, Aiken et al. 1999, Heyman and Graham 2000). In Belize, these fisheries are small scale, characterized by skiffs owned by a senior operator or jointly owned, with medium to low investments and a middle-income level (Berkes et al. 2001). At the same time, these fisheries share characteristics with large-scale fisheries. They depend on fossil fuel, are commercial, and mainly sell catch to organized and international markets. In 1998, 12.2 million BZ\$ and 3 million BZ\$ worth of lobster and conch, respectively, were exported (2 $\mathrm{BZ} \$=1$ US\$), accounting for 74 and $20 \%$ of earnings from export of wild-caught marine produce, respectively (Belize Fisheries Department 2001). These fisheries are also an important source of employment, with 2000-3000 fishers, and 200 workers to process the catch (Food and Agriculture Organisation (FAO) 2001). Unlike the large commercial fleets exploiting pelagic stocks, these fishers are directly dependent on national stocks, as they cannot easily relocate if stocks decline. Despite this dependence and being less capital intensive, small-scale fisheries can also demonstrate pathological resource use (McManus 1988, Smith and Berkes 1991, Hughes 1994).

The overall objective of this paper is to analyze how these fisheries have developed and responded to changes in resource abundance. I will focus in particular on technology and organizations in the industry and their effect on these fisheries' sensitivity to environmental feedback. The results first present the regulations for the industry in the context of the fishing grounds used and the lobster and conch life cycles. This is followed by a history of the development of these fisheries at a national level, as well as identifying differences within the country. The discussion focuses on the social and ecological resilience of the Belize lobster and conch fisheries. I conclude that fossil fuel-based technology, property rights, and the organizational structure of the fishing industry have trapped these two fisheries into the pathology of resource use, and created a positive feedback loop that is increasing vulnerability for lobster and conch fishing in Belize. All locations referred to in the paper are shown on Fig. 1, all fishing gear and boats are described in App. 1, and a chronology of the development of the lobster and conch fishing is summarized in App. 2. 


\section{DATA AND METHODS}

There are many actors involved in the fishing industry, however, this study concentrates on the fishers, the cooperatives, and the Fisheries Department. Three forms of data on changes in lobster and conch catches and on the causes and effects of these changes were collected: catch statistics and number of fishers at the national level; qualitative data with interviews; and data from the scientific literature and archive searches at the Belize National Archives.

\section{Statistics on Production and the Number of Fishers}

Catch and export statistics were used to compile a time series for production (Fig. 2). Export statistics were used as a substitute for production data for the period 1923-1968, as the latter were not collected. From 1977 onward, production data are available from the Fisheries Department. For lobster, the data are separated into different products (Belize Fisheries Department 2001). Of these, the tail and head meat categories were converted to whole lobster using the conversion factor " 2 " applied by the FAO for the inclusion of these data in the $F A O$ Yearbook of Fishery Statistics-Capture Production, in which all capture data are reported in live-weight equivalents. To avoid double counting lobsters, only the tail weight was converted. This conversion factor was calculated in a previous year in which Belize's correspondent provided both live weight and tail weight of lobster (Mr. Garibaldi, Fishery Statistician FAO, personal communication 2001).

Production data are collected from the cooperatives by the Fisheries Department. All data exclude catch sold on local markets, directly to restaurants, and illegally across the border (King 1997, Heyman and Graham 2000). The colonial government collected little fisheries data until the 1950s, however, local consumption was low (see below) and there were few exporters, so it is believed that these figures are a good representation of total catch. From the 1960s onward, the cooperatives offered the highest prices for lobster and conch, which would have encouraged fishers to sell to the cooperatives and should, therefore, make the data a good representation of total production. Since the 1980s, the tourist industry has boomed and increased the national market for lobster and conch. This market has grown with restaurants paying prices competitive with those paid at the cooperatives. In other words, there is a growing catch that is unaccounted for in the official statistics, but it was not possible to estimate its size.

The numbers of fishers up to 1993 are estimates from the colonial government and the literature (1946-1955: Colonial Government 1947, 1955, 1957; 1957, 1960s, mid-1970s: Gordon 1986; 1973: Baird 1973; 1985: Daly Price 1986; 1989: Pinto and Vasquez 1989). From 1993 onward, these statistics are from the Fisheries Department (for 1993-1998 in Central Statistical Office (CSO) 1999, and for 1999 in Coastal Zone Management Authority and Institute (CZMAI) 2000). Estimates are not believed to be accurate. From the 1950s to 1960 s, lobster was landed in Belize City; therefore, it is likely that these estimates account for the big producers, but underestimate the total. Although the high prices paid by the cooperatives from the $1960 \mathrm{~s}$ onward will have encouraged fishers to sell their catch there, they did not have to be members as they could sell directly to the cooperative or indirectly via other members. This means that using the number of cooperative members cannot substitute for missing fishing license data; this is particularly true in recent years, with the growing national market offering good prices for catch. These data are not, therefore, felt to be reliable.

\section{Interviews}

Because of insufficient data to calculate changes in catch per unit effort, interviews were conducted to verify and complete existing data. The author conducted interviews during five field visits between 1998 and 2002. Between 1998 and 2000, interviews and discussions were carried out with various stakeholders, including fishers, cooperative board members, non-governmental organization (NGO) representatives, and Fisheries Department officials. Interviewees were usually initially chosen at random: depending on who was in office or available at the time of the visit. Cooperative board members interviewed were recommended by Fisheries Department officials and NGO representatives. All of these informants were visited during subsequent field visits. Fishers were interviewed in Belize City at the two cooperatives' landing sites, at the local market, and on Caye Caulker (Fig. 1). These meetings provided a wealth of background information on past and recent events in the fishery 
Fig. 2. Lobster and conch production, and the number of fishers in Belize (1923-2001). Export data were used when production statistics were not available.

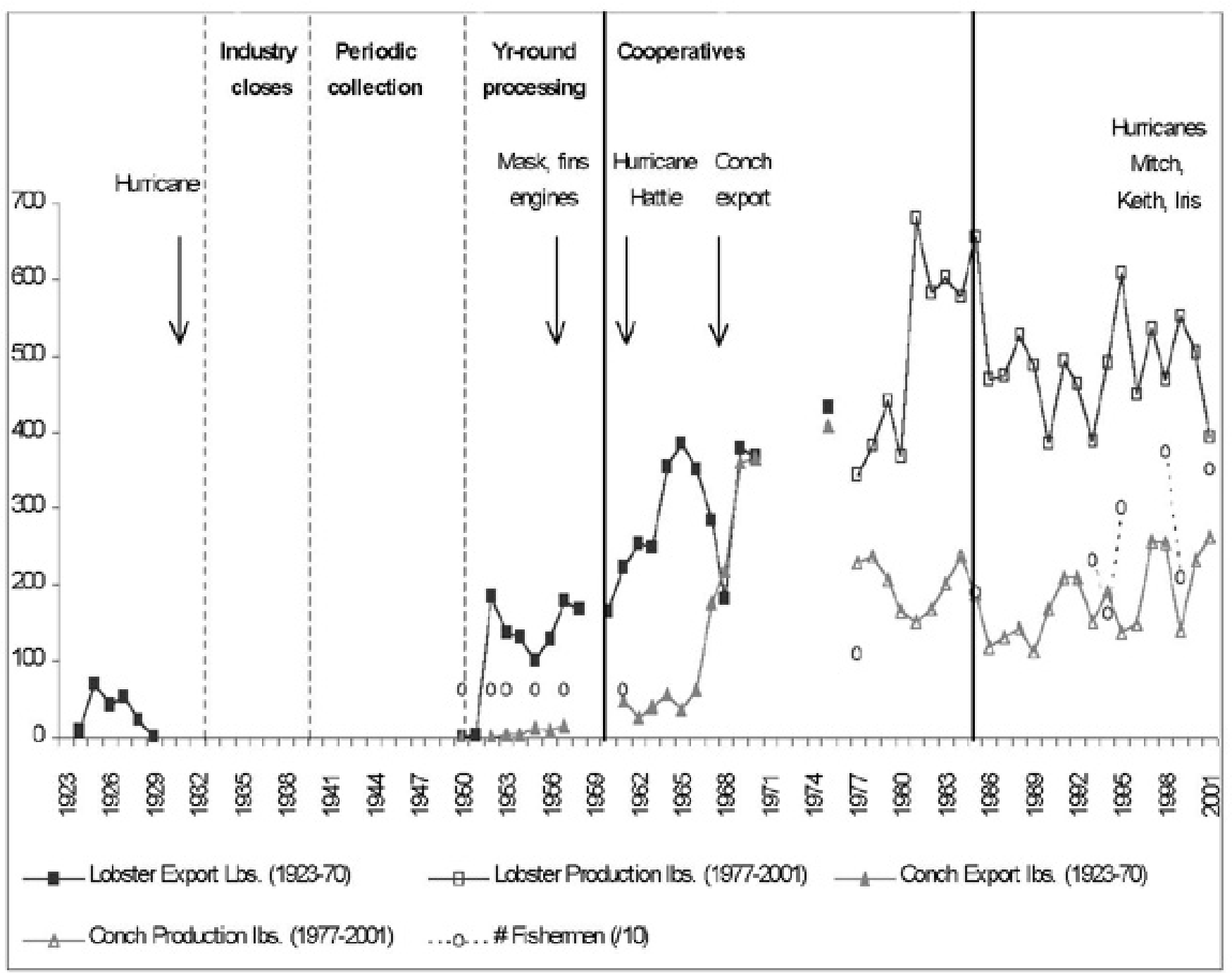

at both local and national scales.

In 2002, 16 key informants (Bernard 1994) were interviewed and, of these, 11 were interviewed in depth (Table 1). Due to time constraints, fishers were not targeted because of the great heterogeneity among them. Also, past studies that interviewed fishers provided good information on changes in catch and possible causes of these changes (Espeut 1994, Jacobs 1999, Heyman and Graham 2000, see also Table 2). The main target group was cooperative board members, and at least one board member from each cooperative was interviewed. Most had over 40 years' personal experience as fishers, and were knowledgeable on their membership, on the fisheries, as well as the socioeconomic factors affecting fishers at both local and national scales. The cooperative in Punta Gorda was recently established at the time of this study, and the chairman of the board had not been a member of the former cooperative. A local NGO recommended a former fisher, now tour guide, with 
over 50 years' experience of fishing in the area. He had been a productive member of the former cooperative in the 1960s and had knowledge of local history that has affected fishing in the region. The remaining key informants had at least 10 years' experience with the fishing industry in Belize, and most of these individuals represented more than one category of stakeholder (Table 1).

Qualitative and semi-structured interviews (Kvale 1996) were chosen as they provided more detailed accounts of change, which was particularly relevant for building up a history of the fishery and identifying key past events. Given the interest in developing a more complete history of the fishery's development in the south, informants from the Fisheries Department, the Cooperative Department, and local NGOs working with local fisheries were also interviewed. Interviews usually consisted of two meetings. Interviewees were asked about their personal history in the industry, changes in catches and causes, and changes in gear, boats, grounds, and numbers of fishers. Most interviews took place in the informant's work place. In order to protect the identity of interviewees who chose to remain anonymous, all interviewees are anonymous.

The credibility of interviewees and of their responses was gauged by their position, experience, and recommendation. Interviewees from cooperative boards, NGOs, and the Fisheries Department are expected to have a minimum knowledge to fulfill their position. In the case of the Fisheries Department and the cooperative board members, an understanding of the fisheries at the national level is expected given their membership and as cooperatives are represented in the Fisheries Advisory Board that advises the Minister on policy at national and local levels. Experience was rated both by the number of years involved in the fisheries, as well as the range of experience within the fishery. Finally, when a third party recommended interviewees, this was expected to be related to the interviewee's experience and trustworthiness. The three sources of information (statistics, interviews, and information in the scientific literature and national archives) were compared to identify and confirm trends.

\section{RESULTS}

\section{Lobster and Conch: Life Cycle, Fishing Grounds, and Regulations in Belize}

The Caribbean spiny lobster, Panuliris argus, and the queen conch, Strombus gigas (referred to as lobster and conch, respectively), are found throughout the tropical western Atlantic and Caribbean. Both have a larval phase in the open water. Lobster remain in the zooplankton for up to a year, compared with conch that only stay for up to 4 weeks (CFMC/CFRAMP 1999, FAO 2001).

Settlement depends on the number of eggs released and subsequent larvae survival. The number of eggs released is related to the number of females that reproduce in a year and their fecundity. Survival of larvae depends on physical and chemical conditions and predation. The short larval period for conch most likely means that this is largely a self-seeding population. A study comparing lobster from Caye Caulker and Glovers Reef Atoll (Fig. 1) found little genetic variation between the two, suggesting that they are of the same stock, with a possibility of a sub-population on Glovers Reef Atoll (Glaholt and Seeb 1992). Silberman et al. (1994) studied the mitochondrial DNA of lobster in the Caribbean and concluded that the region's lobster population is genetically homogenous, and attributed this to the long larval period that allows for wide dispersion. This study did not sample between the Yucatan and Costa Rica, which prevents comparing these two studies' results. The Guiana Current flows northward to the east of Belize's atolls (Silberman et al. 1994), however, the current in front of the barrier reef and in the lagoon is southward flowing (Craig 1966). These currents may mean that Belize's lobster population is partly self seeding, although to what extent is unknown. A gyre to the east of Glovers Reef Atoll (Craig 1966, Heyman and Kjerfve 1999) may make this atoll self seeding, and account for Glaholt and Seeb's (1992) results.

Postlarvae of both species migrate into shallow (2 m) nurseries, where they settle and metamorphose into juvenile lobster and conch (FAO 2001). Conch settle in seagrass beds, and lobster in both mangroves and seagrass beds. Both avoid areas prone to freshwater intrusion and turbidity (Acosta and Butler 1997). Young spiny lobster are prone to predation, with up to $99 \%$ mortality within the first year of settlement (Butler et al. 1997). As lobster increase in size, predation decreases in importance. 
Table 1. Summary of interviews and key informants. The informants have been classified according to their main category as a stakeholder and where they are from or were interviewed (PG - Punta Gorda; PL Placencia; BC - Belize City; SP - San Pedro). These informants were asked about at least one of the following: (1) Cooperative structure: board and duties, infrastructure, membership numbers and changes; (2) Cooperative history: main events/crises, cooperative's function, member loyalty; (3) Landings: changes and causes, differences in change in the country; (4) Fishing history: changes in gear, boats, catch, grounds, and fishers, details about the south's history.

\begin{tabular}{|c|c|c|c|c|c|c|}
\hline \multirow[b]{2}{*}{ Informant } & \multirow[b]{2}{*}{$\begin{array}{l}\text { Additional stakeh- } \\
\text { older category }\end{array}$} & \multirow[b]{2}{*}{ Interviews $(\mathrm{N})$} & \multicolumn{4}{|c|}{ Information Categories } \\
\hline & & & (1) & $(2)$ & (3) & (4) \\
\hline Cooperatives Dept. (PG) & & 1 & $\mathrm{X}$ & & & \\
\hline Fisheries Dept. Officer (PG) & & 1 & & & $\mathrm{X}$ & $\mathrm{X}$ \\
\hline Fisheries Dept. Officer (PG) & & 1 & & & & $\mathrm{X}$ \\
\hline NGO (PG) & Fisherman & 1 & & & & $\mathrm{X}$ \\
\hline Tourism (PL) & Fisherman, NGO & 3 & & & $\mathrm{X}$ & $\mathrm{X}$ \\
\hline NGO (PL) & Fisherman & 2 & $\mathrm{X}$ & $\mathrm{X}$ & $\mathrm{X}$ & $\mathrm{X}$ \\
\hline Fishermen's Cooperative (PL) & Fisherman, NGO & 3 & & & $\mathrm{X}$ & $\mathrm{X}$ \\
\hline Fishermen's Cooperative (BC) & & 1 & $\mathrm{X}$ & $\mathrm{X}$ & $\mathrm{X}$ & \\
\hline Fishermen's Cooperative (BC) & Fisherman & 2 & $\mathrm{X}$ & $\mathrm{X}$ & $\mathrm{X}$ & \\
\hline Fishermen's Cooperative (BC) & Fisherman & 1 & $\mathrm{X}$ & $\mathrm{X}$ & $\mathrm{X}$ & \\
\hline Fishermen's Cooperative (SP) & & 1 & $\mathrm{X}$ & $\mathrm{X}$ & $\mathrm{X}$ & \\
\hline Total stakeholders interviewed: & $\mathrm{N}$ & $\mathrm{N}$ & & & & \\
\hline Cooperatives & 6 & 10 & & & & \\
\hline Fishermen & 6 & 9 & & & & \\
\hline Government & 3 & 3 & & & & \\
\hline Other (warden, NGO, tourism) & 6 & 7 & & & & \\
\hline
\end{tabular}

As they mature, both migrate into deeper water, conch into seagrass beds and lobster to the reef. Juvenile lobster ( $2-4$ years old) become nomadic in the area behind the reef $(3-10 \mathrm{~m})$ during the transition from nursery to reef. As sub-adults, they migrate to the reefs and first reach sexual maturity (78-83 mm carapace length) up to 10 years after spawning (FAO 2001). Lobster molt their outer skin to increase in size. It is illegal to collect "softshelled" lobster. This refers to the state of lobster following a molt, when they are particularly vulnerable to predation. In a synthesis of data from the Caribbean, the size at first maturity, the smallest size for a reproductive lobster, was between 78-83 $\mathrm{mm}$ carapace length (FAO 2001). The legal minimum size for lobster is $76 \mathrm{~mm}$, which probably means that few females entering the fishery are sexually mature.

Adult lobster take shelter on the reef during the day, and forage in seagrass beds at night. Lobster also migrate during certain weather conditions and for 
Table 2. Summary of results from interviews with fishers about changes in lobster and conch abundances.

\begin{tabular}{lccccc}
\hline \hline & $\begin{array}{c}\text { Stann Creek \& Toledo } \\
\text { Districts (1) }\end{array}$ & $\begin{array}{c}\text { Toledo Di- } \\
\text { strict (2) }\end{array}$ & $\begin{array}{c}\text { Belize City } \\
(3)\end{array}$ & San Pedro (3) & Punta Gorda (3) \\
\hline Fishermen interviewed (N) & 75 & 37 & 54 & 29 & 19 \\
Lobster & & & & & \\
Fewer (\%) & 88 & 49 & 82 & 86 & 79 \\
Smaller (\%) & 24 & 43 & 37 & 45 & 53 \\
Conch & & & & & \\
Fewer (\%) & 100 & 46 & & & \\
Smaller (\%) & 24 & 38 & & & \\
\hline
\end{tabular}

Note: Stann Creek and Toledo Districts are the southernmost districts in Belize, stretching from a little north of Dangriga (Fig. 1) to the border with Honduras. References: (1) Jacobs 1999, (2) Heyman and Graham 2000, (3) Espeut 1994.

mating, often in groups called "lobster runs" (Morgan 1980). Trap fishers take advantage of lobster migrations in the seagrass beds, whereas divers target adult lobster on the reef. Reproductive lobster aggregate on the reef. Reproductive females are "berried," which refers to the egg mass that is held on their underside and it is illegal to fish berried females throughout the year. In Belize, females can be berried throughout the year, but numbers peak in May (Acosta 1998). A closed season from 14 February to 13 June protects this peak in mating.

Conch are slow moving and the shell is their only defense. Mortality is high among juveniles because of predation and mortality, with $0.01 \%$ chance of surviving the year following metamorphosis (Stoner 1997). As adults they have few natural predators, but they are vulnerable to fishing and are fished throughout their habitat down to $\sim 30 \mathrm{~m}$ depth. After 2-3 years, juveniles migrate from their nurseries to deeper waters and become sexually mature after 3.5-4 years (CFMC/CFRAMP 1999). Conch shells stop increasing in length once they reach maturity, around $21 \mathrm{~cm}$ (CFMC/CFRAMP 1999), when a lip develops and thickens. The Belizean legal minimum length for conch is $18 \mathrm{~cm}$ and may not, therefore, allow many conch to reach maturity before entering the fishery. Mating is density dependent, requiring relative abundance of around $50 \mathrm{conch} / \mathrm{ha}$ (Stoner 1997). Mating occurs in the summer when adults aggregate in deeper seagrass beds. This is protected by a closed season from the 1 July to 30 September.

The use of poisons, dynamite, SCUBA, and hookah are illegal. Skin divers often maim or kill lobster before being able to check their size or if they are berried, whereas these are easily released from traps. Fishers also claim that lobster learn to escape traps if left unchecked too long (Craig 1966), and this has been observed with American lobster (Jury et al. 2001). If traps are lost, however, according to fishers interviewed on Caye Caulker, traps continue to fish, and can cause habitat damage if dragged over seagrass beds or the reef. This could be overcome by inserting biodegradable doors (Acheson 1988).

Lobster and conch fishing grounds are largely limited to waters less than $30 \mathrm{~m}$ deep, as this is the maximum depth that can be skin dived. Skin diving is also limited by visibility, which is better in the northern part of the main lagoon behind the barrier reef and on the atolls. The southern portion often has lowered visibility and salinity as a result of high precipitation over the Maya Mountains and subsequent river discharge (Heyman and Kjerfve 1999, Fig. 1). These conditions may limit the grounds for both lobster and conch in the south (Acosta and Butler 1997). Also, the lagoon widens and deepens in the south (Gibson et al. 1998, Heyman and Kjerfve 1999), and there is more wave activity, as the barrier reef is deeper and less continuous (Craig 1966). 
Fishing is also disrupted by frontal storms and hurricanes. Six hurricanes have affected Belize in the last 100 years (

Belize National Meteorological Service): in 1931, 1961, 1978, 1998, 2000, and 2001. Hurricanes destroy gear and infrastructure, e.g., Hurricane Iris (2001) hit the coast between Placencia and Punta Negra (Fig. 1) and caused an estimated 475 million BZ\$ worth of damage (Government of Belize 2001). Hurricanes also damage the fishing grounds. In 1998, Hurricane Mitch's storm surge damaged windward reefs throughout Belize (Mumby 1999, Andrefouet et al. 2002). Seagrass beds tend to be sheltered by the reef from wave activity, but Hurricane Keith (2000) hit the northern lagoon and its cayes, and destroyed these grounds for lobster and conch.

\section{History and Development of Lobster and Conch Fishing in Belize}

Belize was claimed by the Spanish in the $16^{\text {th }}$ century, and seized by the British in 1798, becoming British Honduras in 1862 (Bolland 1997). In 1973, the colony's name was changed from British Honduras to Belize, and Belize gained independence on September 21, 1981. I have chosen to refer to Belize and Belize City, formerly British Honduras and Belize respectively, throughout the paper. Market prices for timber and sugar, the colony's main exports, fell in the early $20^{\text {th }}$ century and were followed by the global depression (Gordon 1986). This, and loan charges following the 1931 hurricane, prevented the colony from balancing its budget from 1931 onward (Colonial Government 1952a).

Until the early $20^{\text {th }}$ century, fishing was limited to a few fishers in the vicinity of Belize City (Daly Price 1986) and there were few markets for fish in the colony, which limited the number of people who could make a living from fishing (Gordon 1986). Until the early 1900s, independent fishing was restricted to the Garifuna in the south and the Mestizos in the north (Craig 1966, App. 2). The main targets were fish and turtle that were fished from dories with hand lines, harpoons, nets, traps and weirs (Daly Price 1986, App. 1). At the end of the $1800 \mathrm{~s}$, conch meat was consumed in small quantities (Morris 1883) and, according to newspapers at the time, there were canneries processing lobster, conch, and crabmeat (R. Wilk, personal communication 2003). This was probably not in large quantities as lobster was "eaten by the poor because it was abundant, by the elite because it was rare in Europe, but shunned by the middleclass as a "trash fish"" (Wilk 1999). In the early 1900s, foreigners saw the opportunity to market spiny lobster as a substitute for the North American lobster (Gordon 1986), whose yield was in decline (Acheson 1988). Below, I summarize the changes in production of lobster and conch over time, and the responses by the main organizations in these fisheries.

\section{Changes in Production}

Both lobster and conch were reported to be very abundant prior to exploitation. For example, two cooperative board members, who were fishing when the cooperatives were established and witnessed the introduction of conch as an export good, explained that "you did not fish for conch," you rolled up your trousers and waded from the shore to collect conch. Despite the low pay compared with lobster (conch prices have always been lower than lobster), conch fishing provided a living because of its abundance. Later, the looking glass and eventually skin diving were needed to fish conch. Similarly, a cooperative board member explained that, in the past (pre-1960s), "fishermen saw so many lobsters that they did not think that they could run out."

National lobster production has fallen on three occasions since the 1950s: in the early 1950s, late 1960s, and early 1980s (Fig. 2). Since the 1980s, lobster and conch production have been relatively stable (Fig. 2). Cooperative board members reported that yields at the national and cooperative levels are stable, but are declining at the individual fisher level despite increased effort (see also Table 2). National conch landings peaked in 1975 (Fig. 2), but the first conch grounds were in decline by the early 1970 s (Baird 1973). After 1975, conch landings plummeted, and have never recovered (Fig. 2). All of the interviewees, commenting on the changes in conch, believed that the crash in production was a result of fishing, which is supported by earlier studies (Jacobs 1999, Heyman and Graham 2000).

The literature reports local declines in production throughout the history of lobster fishing. For example, in the 1920s, Capt. Foote, despite being one of the first and only lobster exploiters in Belize, was forced to move his operations because of local 
declines in abundance of lobster (Daly Price 1986; App. 2). In the mid-1980s, gillnets (App. 1) were introduced in Monkey River (Fig. 1) to fish lobster. Two key informants from this area who witnessed this introduction, reported that gillnets produced large yields, with 50 -foot $(15.24 \mathrm{~m})$ nets catching up to 150 lobsters. Fishers built new houses and bought new boats at the end of these fishing seasons. The catch stabilized after 2-3 years, despite continued investment in gillnets, and these were finally abandoned. The key informant from Punta Gorda recollected large lobster catches from the Snake Cayes (Fig. 1) in the 1960s. The closeness to shore of these cayes suggests that lobster had not yet become an important target in the south. At the time of the study, several interviewees from Belize City reported that lobster in the south are larger than in the north. However, the south has also suffered reduced catch and size of both lobster and conch (Table 2).

Hurricanes also temporarily disrupt fishing. In 1961, Hurricane Hattie destroyed processing equipment in Belize City and fishing gear from the north to Belize City, and impacted fishing grounds (Craig 1966). Accounts in Craig's (1966) work reported that Lighthouse Reef Atoll's grounds had not recovered 4 years later. Nevertheless, both processing and national lobster landings recovered within a year (Barclays Bank 1962, Fig. 2). Following the recent hurricanes, however, lobster landings have fallen to their lowest level since 1993 (Fig. 2), despite a boom in catch in the south for the fiscal year 1999-2000 (Government of Belize 2000). Cooperative board members reported that fishers from Caye Caulker have accounted for $40 \%$ of their membership, but over half of their lobster production. After Hurricane Keith, lobster yields from Caye Caulker declined by $60 \%$.

\section{Response to Changes by Fishers, Cooperatives, and the Fisheries Department}

As local catches declined, fishers extended their grounds (Fig. 3). Until the 1950s, fishers from San Pedro caught lobster within a day's journey of the village, and catches of 300-400 lobsters within a mile of the island were common (Gordon 1986). San Pedro's fishing grounds had stretched from the southern tip of Ambergris Caye to the northern tip of Caye Caulker, and from the reef to Cayo Congrejo (Fig. 1), but fishers now needed to travel further (Gordon 1986). The two main fishing methods used were traps and bully nets (App. 1). In 1953, fishers could collect 100-200 lobsters per day with bully nets. By 1955, bully nets were abandoned because they were no longer profitable (Daly Price 1986). By the 1950s, trap fishers in the north had established informal territories in trappable grounds, a system that persists today (King 1997). At the end of the 1950s, lobster production began to decline. The grounds included all trappable grounds northward of Belize City, as well as in Turneffe Atoll's lagoon, and by 1957, all trappable grounds were fully claimed (Fig. 3). This prevented fishers who had been using bully nets from continuing to fish (Daly Price 1986).

The introduction of skin diving, outboard engines, and improved access to ice in the late 1950s assisted the spread of fishers and the intensification of trapping. Skin diving allowed former bullynet fishers and new fishers to join the fishery as it targets lobster on the reef where traps cannot be used. Fishers traveled to the comparatively unexploited atolls where catches were so large, over $220 \mathrm{~kg}$ of tails per day, that fishers began to land only tails, as these fetched a better price than whole lobster (Gordon 1986). The introduction of skiffs in the 1980s made all grounds readily accessible to fishers throughout the country, and allowed further trap intensification, as more traps could be checked per day. Despite these improvements, by 1986, it was rare to catch more than $500 \mathrm{~kg}$ of lobster on a 10day fishing trip (Gordon 1986). The cooperative board members interviewed reported that, although trap fishers in the north have been the most productive lobster fishers in Belize, they have been increasing effort but not their catch. In the 1940s, fishers had an average of 10-15 traps, which increased to around 100 traps per fisher with the advent of outboard engines (Daly Price 1986). A cooperative board member reported that fishers now have up to 1200 traps, checking between 350 and 400 traps every 2 days, although their catch has not increased (Fig. 4). Another board member claimed that there are so many traps in the lagoon that no lobster can make it to the reef.

Fishers were aware that proceeds from sales abroad were not fairly distributed throughout the industry's development, but they lacked the capital needed to process, market, and export the catch (Bradley 1956). In 1960, 39 fishers from Caye Caulker came together to form the Northern Fishermen's Cooperative Society (Sutherland 1986). In 1965, the 
Fig. 3. Sequential exploitation of the fishing grounds over time.

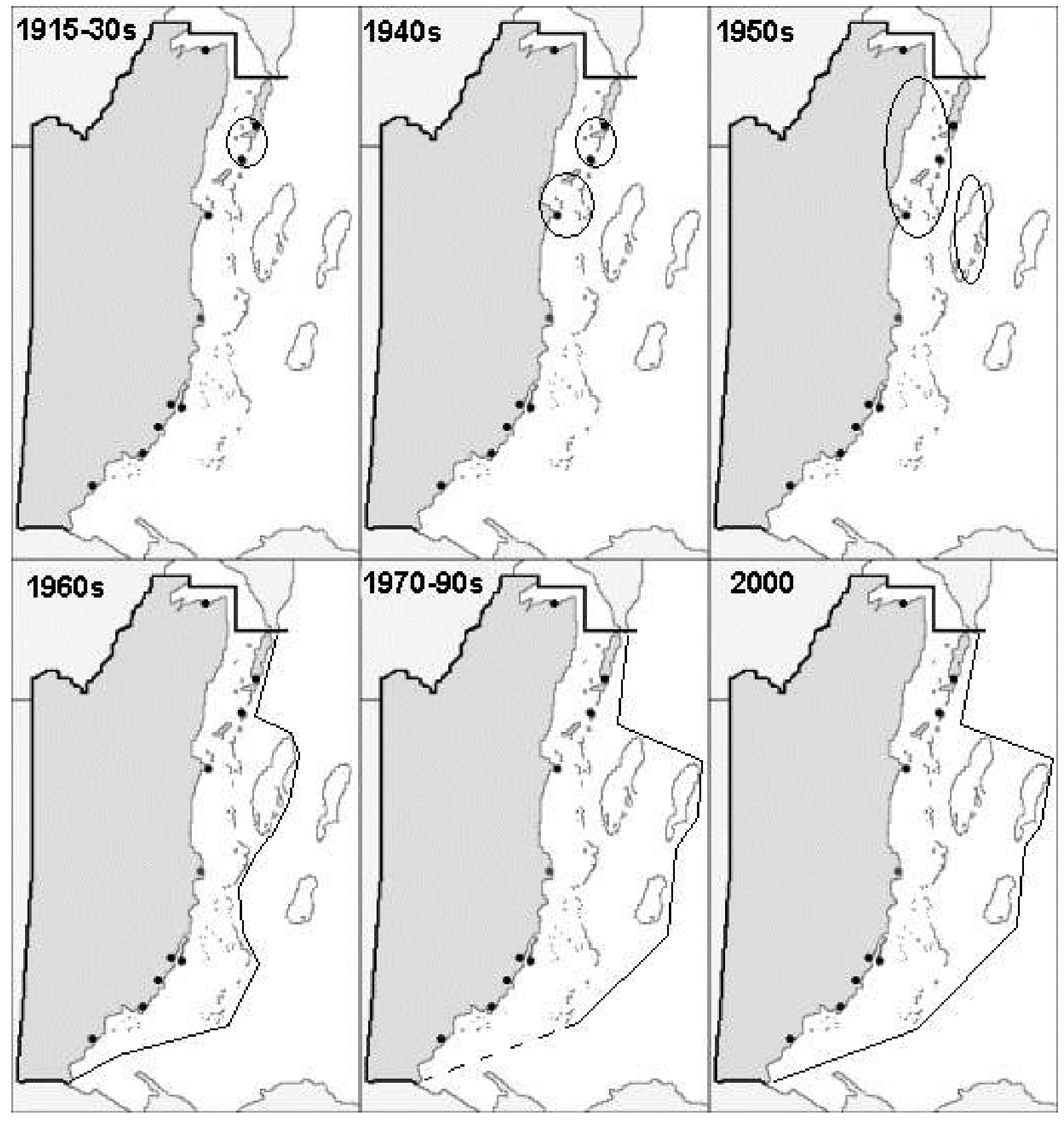


Government of Belize passed a law that only cooperatives would be granted export quotas (Daly Price 1986). This shut down all foreign exporters, and ensured that the revenues from the export of marine products remained in Belize. Many cooperatives were started in subsequent years, although most were short lived (Belize Fisheries Department 2001). Four cooperatives have persisted: Northern Fishermen's Cooperative Society and National Fishermen Producers' Cooperative Society based in Belize City, Placencia Producers' Cooperative Society in Placencia and Caribeña Producers' Cooperative in San Pedro. Since the early 1990s, when the cooperatives in Placencia and San Pedro discontinued processing and exporting their catch because of increased costs and decreased landings, the two cooperatives in Belize City have dominated the industry. A more recent change has been improved infrastructure in the south (Fig. 3). In response to decreased yields in the north after Hurricane Keith, the Northern Fishermen's Cooperative Society opened a receiving station in Mango Creek (Fig. 1) to encourage their members to move southward and, in 2001, the Rio Grande Cooperative was established in Punta Gorda.

Fig. 4. A fisher's lobster traps stacked on the beach on Caye Caulker.

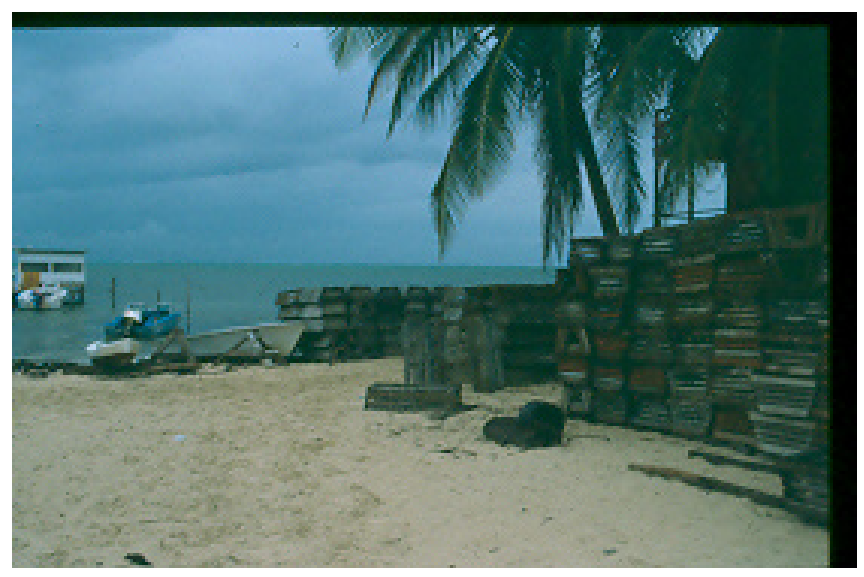

Fishers' incomes jumped by over $1000 \%$ in less than 5 years after the establishment of the cooperatives (Godfrey in Sutherland 1986). In the 1980s, the average salary of a lobster fisher was five times greater than the average per capita income and twice the salary of civil servants (Central Statistical Office statistics in Daly Price 1986). In addition to improved distribution of export earnings, the cooperatives provided financial support, through loans, allowing members to invest in technology, and local cooperatives gave local fishers access to the export market. In the 1960s, a cooperative opened in Punta Gorda, but closed before the end of the 1960s. The informant from Punta Gorda was a member of this cooperative and explained that fishers in, and to the south of, Punta Gorda stopped targeting lobster following the closure of this cooperative as there was no longer a buyer and it was too expensive to travel to the cooperative in Placencia.

Although conch production crashed in the late 1970s (Fig. 2), high lobster prices allowed displaced conch fishers to switch to lobster and continued to attract new fishers. Cooperative board members in Belize City explained that, in the 1980s, the cooperatives began to offer incentives to attract fishers to join the cooperative, such as offering private loans, or simply to sell their catch to the cooperative. These measures were taken despite existing problems regarding loan repayment (Daly Price 1986, Sutherland 1986) and regulations prohibiting the buying of catch from non members (Government of Belize 2000). So, fishers could now sell their catch to other cooperatives, their own cooperative via another member, or directly to restaurants to avoid loan debits. Today, all of the cooperatives have problems related to loan abuse, and a board member estimated that $70 \%$ of its membership was in debt. There was a feeling of disappointment by all of the cooperative board members vis à vis their young members, who were perceived to be less loyal. They attributed this, in part, to their having been born into the cooperatives and never having needed to fight for them.

With increased incomes, fishers could pay for further schooling for their children, who have turned to other kinds of work (Gordon 1986, King 1997). Cooperative board members reported a change in the composition of fishers as the number and proportion of new fishers has grown, while traditional fishers have retired or left the industry. Many fishers have switched to tourism, becoming, for example, tour guides, or selling their catch directly to the tourist industry. A cooperative board member explained that many young fishers were turning to tourism because it guaranteed a paycheck 
at the end of the day, which fishing could not do. The tourist industry has also increased national demand for and consumption of both lobster and conch. A cooperative board member explained that the tourist industry could begin to compete with the export market, particularly for lobster. This would force the cooperatives to increase the local price for lobster, which is presently sold at $60 \%$ of the export price.

Until the 1950s, marine products made up less than $1 \%$ of national exports (Thompson 1944). By the early 1950s, the lobster industry was considered an established industry by the government, and export duties were established (Bradley 1956). In 1948, the Fisheries Ordinance set the framework for future fisheries regulations. In 1950, a Fisheries Officer was appointed and was responsible for data collection and monitoring of the stocks and enforcement, and the Fisheries Unit (now the Fisheries Department) was established a year later (Colonial Government 1952a, b). In addition to the regulations presented earlier, these established fishing and boat licenses. The first marine reserve was established in 1987, with fisheries conservation among its goals (McField et al. 1996). By 2000, there were 12 marine protected areas, covering about $16 \%$ of Belize's territorial waters, with less than $1 \%$ in no-take zones (CZMAI 2000). Illegal fishing of undersized and berried females was already reported in the 1970s (Baird 1973). Most interviewees reported illegal fishing by both foreigners and locals. This included taking undersized and berried lobster, as well as crossborder smuggling of catch out of season and when prices were higher in neighboring countries. In the south, there seem to be more serious problems with fishers from Guatemala and Honduras coming to fish in Belize's water. There are no estimates on the amount of production this activity might account for.

\section{DISCUSSION}

\section{Sequential Exploitation and Masking Environmental Feedback}

Understanding and monitoring of both the resource and its ecosystem dynamics is a prerequisite for response to environmental feedback (Berkes and Folke 1998a). This requires monitoring over space and time to identify processes, to adapt to them, and to create a memory of this interaction (Berkes and
Folke 2002). There have been several occasions when the opportunity to learn from crises was missed (Gunderson 2003). Missed crises are defined here as large-scale events that could have been used for learning about the impacts of disturbances on lobster and conch and their ecosystems. The closure of the lobster fishing industry after the 1931 hurricane will have reduced the monitoring of its impacts on the fishing grounds. The 1961 hurricane coincided with the introduction of skin diving and engines. The rapid diffusion of this technology masked both hurricane-induced and fishing-related declines in catch at the end of the 1950s. The concept of sequential exploitation was useful to identify important turning points in the fishing industry. Sequential exploitation was a response to, but also masked, declines in production and in this sense, was a symptom of the pathology. Four forms of sequential exploitation were identified during the industry's development:

1. Sequential exploitation of stocks, moving from large to small individuals.

2. Switching to new targets, from conch to lobster.

3. Concomitant with the above is the sequential exploitation of fishing grounds.

4. This was made possible by the sequential exploitation of fishing gear.

As grounds filled and lobster catches declined in the 1950s, fishers increased effort until appropriation became technology limited. Skin diving and engines permitted intensification of extraction and access to new grounds. Increased prices through the cooperatives acted in synergy with this technology to mask the declines in catch at the end of the 1950s. Until the 1950s, the fisheries in Belize were artisanal, but they then became commercial, albeit small-scale, fisheries (Berkes et al. 2001). The exploitation of conch followed a clear boom-andbust pattern. When the cooperatives began to export conch, and therefore pay higher prices, it was abundant and easy to catch and fishers had access to all of the fishing grounds, as well as to skin-diving gear; the crash in the conch catch appears to have been caused by fishing. High market prices for lobster allowed conch fishers to switch to lobster, and also masked the stabilizing lobster yields in the 1980s. Although the fishery is heterogeneous in terms of ethnicity, environment, targets, and 
socioeconomic conditions, all commercial fishers depend on fossil fuel and an export market, although this may be changing with the growing national market.

Many have stressed the value of the knowledge accumulated among appropriators (Acheson 1988, Berkes et al. 2001, Johannes 2002), and there are contemporary resource management systems that have built local ecosystem knowledge over decadal times scales (Smith and Berkes 1993, Olsson and Folke 2001). Lobster and conch fishing is relatively young in Belize (see for example Ruddle et al. 1992), and this may affect the extent of knowledge of these resources and their dynamics. The belief that lobster could not be overexploited suggests that understanding of certain processes in the lobsters' life cycle was lacking. Nevertheless, this and past studies show that fishers in Belize are aware of declines in abundance, as well as of possible causes of and solutions to these declines (Espeut 1994, Heyman and Graham 2000). This will be an important source of information until regular monitoring can be established (Johannes 1998). This is particularly topical as the composition of the fishery is changing and memories of past events and ecological knowledge may be lost. A telling anecdote was related during an interview with Dr. Heyman of The Nature Conservancy in Punta Gorda. A trip was organized by the Toledo Institute for Development and Environment (TIDE), a local NGO, for 21 local fishers to visit Belize's marine reserves. Older and younger fishers responded differently to the large abundances of fish seen in certain reserves. Older fishers were surprised and recollected that this was how the grounds used to be, whereas the younger fishers were surprised because they had never seen such abundance. These were all either older established fishers or their children or relatives, yet the past was not being transmitted. This is an example of a shifting baseline (Pauly 1995).

\section{Driving Forces in the Lobster and Conch Fisheries}

In his thesis, Craig (1966) concluded that the differences in fishing in Belize were a reflection of cultural differences between relatively isolated groups. These groups were not, however, isolated from each other. Very early, Mestizos in the north adopted the dorey from the Garifuna in the south and later transmitted the smack to the south (Daly
Price 1986). In the case of the lobster fishery, the initial concentration of infrastructure in Belize City and on the northern cayes may have been due to environmental differences that lowered the costs of fishing in the north relative to the south. Nevertheless, development in the south has been similar to that in the north, the main differences being the later arrival of skiffs, the greater diversity of gear used to fish lobster, and the limited presence of the cooperatives.

Expansion of fishing grounds has often been limited by technology. For example, the sailing smack allowed access to distant fishing grounds (Fig. 5). Until ice was introduced in the late 1950s, however, the distance traveled was restricted by how long the catch remained fresh before reaching markets. Similarly, until skin diving was introduced, lobster production was restricted to trapping, once bully nets had become unprofitable. This limited entry to the fishery, as well as the extent of the grounds, as it is impractical to transport traps over long distances.

Fig. 5. Sailing smacks moored in Belize City.

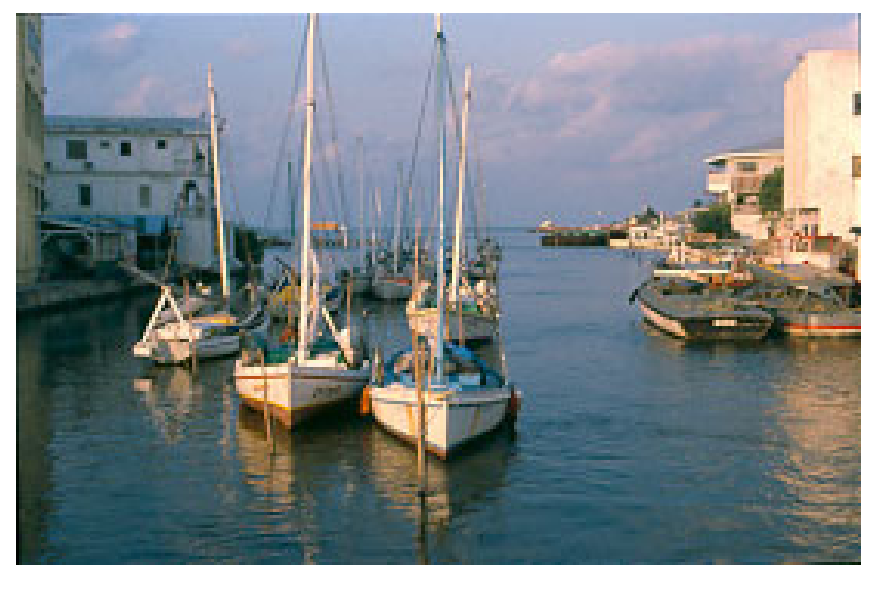

The presence and size of a market also restricted the fishing industry. The scarcity of lobster in the USA was the first driver for lobster fishing in Belize, and provided the first unsaturated market for fisheries products. Lobster became a high-value export commodity, but the benefits were restricted to middlemen. Until the $1950 \mathrm{~s}$, there were few exporters and these visited periodically (App. 2). 
This changed with the establishment of year-round processing in Belize City. Although the low prices paid by exporters could have been a disincentive to fish, the increase in production following the start of year-round processing (Fig. 2), suggests that lobster fishing had indeed been limited by the presence of a buyer. The economic situation in the colony after the 1930s gave people few options. Also, coconut plantations were the main source of employment on the northern cayes, which was hard work for little pay compared with lobster fishing (Sutherland 1986). Fishers needed access to landing sites that supplied the export market, as local markets were saturated. Without this, new technologies were not useful. Based on the impacts of the opening and closing of the cooperative in Punta Gorda in the 1960s, it seems that the lack of access to the export market in the south, via a cooperative, has been a main factor slowing the development of the fishing industry in the south.

Belize is atypical in the Caribbean for its strong and active fishers' cooperatives (Brown and Pomeroy 1999). The cooperatives were essential in permitting a fairer distribution of the benefits from the industry, which has generated wealth and created opportunities in local communities (Gordon 1986, Sutherland 1986). This has been a great success of the cooperatives. The cooperatives increased fishers' income by providing direct access to an unsaturated foreign market. The cooperatives developed for economic reasons and not for resource-use management, and their economic impacts have been an important driver of the industry. When cooperative yields stabilized in the 1980s, the cooperatives began to compete with each other for production. The cooperatives created incentives to continue fishing despite declining catches, including direct subsidies, such as for ice and low-interest loans, and indirect subsidies for example, allowing the abuse of loans and providing a landing site to non members. This artificially changes the market risks, rewards, and costs of fishing (Roodman 1996, Myers and Kent 1998). Fishing has become economically constrained by the investment and fuel costs to overcome environmental constraints. This has only succeeded in the short term. The cooperatives are now economically dependent on maintaining, or increasing, production. In other words, more money is required to support an ever more complex structure to maintain status quo in terms of harvest. In effect, there have been several social mechanisms that have masked environmental feedback.

\section{Governance Measures and Structures}

Despite the lack of sufficient biological and ecological data over time at a national level with which to assess the stocks of lobster and conch, there are many indications that both are being overexploited. The three main indicators from this study are: 1) Production has been declining for lobster and stable for conch (although it has never recovered from the crash) despite continued investment and no reduction in the numbers of fishers. 2) Interviewees reported that individual catches are declining; and 3) These results are supported by past interview studies that have also reported smaller sizes for lobster and conch, indicating high pressure.

Insufficient or inappropriate regulations, poor enforcement, or a combination of these factors may be resulting in too much pressure on lobster and conch stocks. As productivity and predictability of lobster and conch, and of fishers' behavior, decrease, the risk of overexploitation increases, unless all are effectively governed (Ostrom 1990). This requires rules to control fishers' use of the resource, rules to manage the resource, and the means to monitor both fishers and the resource.

Several interviewees stated that there are lobster and conch today as a result of the regulations (see also in Daly Price 1980) and that, if properly enforced, these would provide sufficient fisheries management. The effect of the regulations on conservation of lobster and conch could not be evaluated because of a lack of enforcement, but based on some of the problems identified earlier, it seems likely that the regulations should be reviewed. Some of them are reviewed below. The minimum size for both lobster and conch are key regulations for maintaining these populations as they should maintain recruitment by allowing lobster and conch to mate before being fished. The success of the remaining rules depends on this measure. Protection of berried females requires lobster to reach maturity before becoming accessible to the fishery. Closed seasons are a means of reducing effort and assume that there is a large enough reproductive population to reproduce during the season. Neither of these minimum sizes, however, is likely to protect a large enough proportion of the young adult populations to maintain egg production. Fecundity in both species increases with size, and a population of large individuals could possibly maintain egg production, however, the reports of decreasing size for lobster 
and conch suggest that this is not likely at present. Maintaining a reproductive population is particularly important for conch, as a reduction below a critical density could increase the rate of reduction of egg production.

There is unlimited entry into the fishery as there is no limit on the number of licenses issued, and there are no restrictions on how much can be fished. Until recently, the cooperatives did not limit entry either and, although the development of territories in the north limits access, there are no limits on gear or the amount of lobster that can be fished. Furthermore, enforcement at all of these levels is poor. Cooperatives do not confiscate or sanction members who deliver illegal catch. Sanctioning also seems to be rare among fishers. Even in the territorial grounds in the north, fishing in another's grounds, even stealing from their traps, is rarely sanctioned (Sutherland 1986). This lack of internal or informal enforcement of conservation rules, which are known to be broken throughout the country, places enforcement costs on the Fisheries Department. As is often the case, the monitoring costs inhibit the enforcement of regulations (Berkes et al. 2001). Marine reserves should act as insurance for potential failure of conservation measures in the fishery. The high costs of reserves, however, have inhibited effective management, and five reserves were reported to be "paper parks" (McField 2000).

Incomplete enforcement and unlimited entry make these fisheries de facto open access and have allowed, and encouraged, fishers to continue fishing despite signs of resource depletion. The masking of environmental feedback and lack of institutional response, together with open access, provide conditions ripe for overexploitation. These fisheries have developed faster than potential impacts could be assessed (Seixas and Berkes 2003). Existing regulations could not control, for example, the new incentives to fish following the establishment of the cooperatives, and resulted in increased investment in technology and numbers of fishers. The result has been short-term social resilience for the cooperatives based on the initial boom period and the assumption that lobster and conch could not be overexploited. As long as fishers resist complying with regulations and the cooperatives remain in competition with each other, there will be a lack of incentives within the fishery to constrain fishing effort. The increased brittleness of the cooperatives further increases the risk of open access resource use, as rent-seeking increases and the fishing community identity decreases. The long-term impacts of this pathology will be the degradation of both ecological and social resilience. In other words, social resilience does not guarantee ecological resilience.

The industry is once again at a technology-limited bottleneck, and may be nearing an ecological and socioeconomic crisis. It is, therefore, at a bifurcation point for management (Finlayson and McCay 1998). The national lobster yield continues to decline despite a boom in production in the south, suggesting that these grounds will not solve scarcity. The recent increased access to grounds in the south will continue sequential exploitation and the pathology as it is taking place under the existing governance measures despite the reports of reduced average size of both lobster and conch in this area. By ignoring signals from the environment, fishers have increased their dependence on the cooperatives to maintain their income through, for example, subsidies and market prices. Will crisis lead to fundamental structural changes as predicted by Holling (1986), and seen in other examples (Berkes 1992, Olsson and Folke 2001), or is this industry trapped in the pathology of resource use? The cooperatives may be forced to become more engaged in management of the fishery because of their economic dependence on it. The cooperatives have not responded to the change in stocks, but to the change in their economies. In the early period, this led to the development of perverse subsidies, but it may now force them to become more involved in management of the stocks. Options facing the industry include finding a new, and abundant, target to replace both lobster and conch; continuing to invest in technology and exploit deeper stocks; and changing the structure of the fishing industry to better suit the dynamics of lobster and conch in their ecosystems and with fishers. These are not necessarily mutually exclusive options, but decisions must be based on all existing information, as well as on monitoring and enforcement capacities. In conclusion, there may be multiple states for the structure of this industry: continuing the pathology may lead to commercial extinction of these fisheries, or to the collapse of the cooperatives, or to a structural reorganization of the cooperatives or the industry, or to a combination of these. 


\section{CONCLUSION}

This study is an example of how the organization of a small-scale fishery can generate large-scale resource use problems. The use of new technology over time and space (by increasing the area of the fishing grounds), together with fossil fuel dependence, have sustained yields at the expense of depleted stocks, preventing learning about resource and ecosystem dynamics, and removing incentives to change fishing behavior and regulation. The results contrast with many other studies on common-pool resources, where common property arrangements have improved resource use and environmental management (e.g., McCay and Acheson 1987, Berkes 1989, Ostrom 1990). The organizational structure of the industry has exacerbated this pattern, in particular through the rapid transformation toward rent seeking in the cooperatives. Decreasing catches have required more organizational and financial resources to maintain the status quo. This is an example where social resilience has not resulted in ecological resilience.

In this way, fishing has become a driving force, rather than a component, of the environmental system. Exploiters have coped with declines in resource abundance through short-term problem solving that has masked environmental feedback. In turn, this has attracted more fishers to the fishery. They have not been able to adapt to, and shape themselves to, the capacity of the coastal ecosystem to sustain the lobster and conch fisheries. Instead, coastal ecosystems have been mined, as reflected in the sequential exploitation pattern described in this paper: harvesting from larger to smaller individuals, then shifting to another species and simultaneously moving into new fishing grounds and intensifying extraction with new gear. The pattern reflects a spiral of exploitation that moves toward increased vulnerability. There have been a few attempts to counteract these trends, such as fishing regulations, marine reserves and possibly private territories, but they have not been very successful. The industry is locked into pathological resource use because of mismatches between the different stakeholders' demands, the regulations and organizations managing their actions, and ecosystem dynamics (Folke et al. 1998).
Responses to this article can be read online at:

http://www.ecologyandsociety.org/vol10/iss 1/art21/responses/

\section{Acknowledgments:}

I would like to thank all of the interviewees, without whom this work would not have been possible. The views expressed in this paper do not necessarily reflect theirs. I would also like to thank the staff at the Belize Archives Department, Coastal Zone Management Authority and Institute, Fisheries Department, National Fishermen Producers' Cooperative Society, Northern Fishermen's Cooperative Society, Placencia Cooperative, Caribeña Producers' Cooperative Society, Rio Grande Cooperative Society, TIDE, Friends of Nature, and The Nature Conservancy for their time and assistance. I am also grateful to Nina Parish, Lisa Deutsch, Carl Folke, Line Gordon, Maria Tengö, and the anonymous reviewers for useful comments on earlier versions of this manuscript. This work has been funded by a grant to the Beijer Institute from the John D. and Catherine T. MacArthur Foundation and from the Swedish Research Council for Environment, Agricultural Sciences and Spatial Planning (Formas).

\section{LITERATURE CITED}

Acheson, J. 1988. The lobster gangs of Maine. University Press of New England, Hanover, Pennsylvania, USA.

Acosta, C. A. 1998. Annual progress report to the WCS: population dynamics of exploited species and "reserve effects" in the Glover's Reef Marine Reserve, Belize. Wildlife Conservation Society, Bronx, New York, USA.

Acosta, C.A. 1999. Benthic dispersal of Caribbean spiny lobsters among insular habitats: implications for the conservation of exploited marine species. Conservation Biology 13:603-612.

Acosta, C. A., and D. N. Robertson. 1999. Annual progress report to the WCS: population assessment of exploited benthic species at the Glover's Reef Marine Reserve/environmental characteristics that promote maximum diversity in coral reef fish 
communities. Wildlife Conservation Society.

Acosta, C. A., and M. J. Butler, IV. 1997. Role of mangrove habitat as a nursery for juvenile spiny lobster, Panularis argus, in Belize. Marine Freshwater Research 48:721-727.

Aiken, K. A., G. A. Kong, S. Smikle, R. Mahon, and R. Appledoorn. 1999. The queen conch fishery on Pedro Bank, Jamaica: discovery, development, management. Ocean and Coastal Management 42:1069-1081.

Andrefouet S., P. J. Mumby, M. McField, C. Hu, and F. E. Muller-Karger. 2002. Revisiting coral reef connectivity. Coral Reefs 21:43-48.

Baird, R. 1973. Report to the Government of British Honduras: fisheries and management potential. Based on work of R. H. Baird, FAO/ TA Marine Biologist. FAO Report No. TA 3203. FAO/UNDP, Rome, Italy.

Barclays Bank. 1962. British Guiana and British Honduras. An economic survey. Barclays Bank D. C.O., London, UK.

Belize Fisheries Department. 2001. Fisheries Statistics. Belize Fisheries Department, Belize City, Belize (Central America).

Berkes, F., editor. 1989. Common property resources: ecology and community-based sustainable development. Belhaven Press, London, UK.

Berkes, F. 1992. Success and failure in marine coastal fisheries of Turkey. Pages 161-182 in D. Bromley, editor. Making the commons work. Theory, practice and policy. Institute for Contemporary Studies, San Francisco, California, USA.

Berkes, F., and C. Folke. 1998a. Linking social and ecological systems for resilience and sustainability. Pages 1-25 in F. Berkes and C. Folke, editors. Linking social and ecological systems. Management practices and social mechanisms for building resilience. Cambridge University Press, Cambridge, UK.

Berkes, F., and C. Folke, editors. 1998b. Linking social and ecological systems. Management practices and social mechanisms for building resilience. Cambridge University Press, Cambridge,
UK.

Berkes, F., and C. Folke. 2002. Back to the future: Ecosystem dynamics and local knowledge. Pages 121-146 in L. H. Gunderson and C. S. Holling, editors. Panarchy. Understanding transformations in human and natural systems. Island Press, Washington, D.C., USA.

Berkes, F., R. Mahon, P. McConney, R. Pollnac, and R. Pomeroy. 2001. Managing small-scale fisheries. Alternative directions and methods. International Development Research Centre, Ottawa, Ontario, Canada.

Bernard, H. 1994. Research methods in anthropology: qualitative and quantitative approaches. Sage Publications, Newbury Park, California, USA.

Bolland, N. 1997. Struggles for freedom. Essays on slavery, colonialism and culture in the Caribbean and Central America. The Angelus Press Ltd., Belize City, Belize.

Bradley, E. Jr. 1956. Fisheries in British Honduras. Commodity Series Paper No.12. The Government Printer, Belize.

Brown, D., and R. Pomeroy. 1999. Comanagement of Caribbean community (CARICOM) fisheries. Marine Policy 23:549-570.

Butler, M. IV, W. Herrnkind, and J. Hunt. 1997. Factors affecting the recruitment of juvenile Caribbean spiny lobsters dwelling in macroalgae. Bulletin of Marine Science 61:3-19.

CFMC/CFRAMP. 1999. Report on the queen conch stock assessment and management workshop. Caribbean Fishery Management Council CARICOM Fisheries Resource Assessment and Management Program, Belize City, Belize.

Colonial Government. 1947. Colonial Annual Reports. British Honduras, 1946. His Majesty's Stationary Office, London, UK.

Colonial Government. 1952a. Colonial Annual Reports. British Honduras, 1950. His Majesty's Stationary Office, London, UK.

Colonial Government. 1952b. Colonial Annual Reports. British Honduras, 1951. Her Majesty's Stationary Office, London, UK. 
Colonial Government. 1955. Colonial Annual Reports. British Honduras, 1953. Her Majesty's Stationary Office, London, UK.

Colonial Government. 1957. Colonial Annual Reports. British Honduras, 1955. Her Majesty's Stationary Office, London, UK.

Craig, A. 1966. Geography of fishing in British Honduras and adjacent coastal waters. Louisiana State University Press, Baton Rouge, Louisiana, USA.

Central Statistical Office (CSO). 1999. Environmental statistics for Belize. CSO, Ministry of Finance, Belmopan, Belize.

Coastal Zone Management Authority and Institute (CZMAI). 2000. State of the Coast Report 1999. CZMAI, Belize City, Belize.

Daly Price, M. 1986. Harvesting Belize's lobster: a geography of a resource and its development. Masters thesis. Syracuse University, Syracuse, New York, USA.

Espeut, P. 1994. A socioeconomic baseline survey of thirty fishing communities in twelve CARICOM countries. CARICOM Fisheries Resource Assessment and Management Program, Kingston, Jamaica.

Finlayson, A., and B. McCay. 1998. Crossing the threshold of ecosystem resilience: the commercial extinction of northern cod. Pages 311-337 in F. Berkes and C. Folke, editors. Linking Social and Ecological Systems. Management practices and social mechanisms for building resilience. Cambridge University Press, Cambridge, UK.

Folke, C., L. Pritchard, F. Berkes, J. Colding, and U. Svedin. 1998. The problem of fit between ecosystems and institutions. IHDP Working Paper 2:1-49.

Food and Agriculture Organisation (FAO). 2001. Report on the FAO/DANIDA/CFRAMP/WECAFC Regional Workshops on the Assessment of the Caribbean Spiny Lobster (Panulirus argus). Belize City, Belize, 21 April-2 May 1997 and Merida, Yucatán, Mexico, 1-12 June 1998. FAO, Rome, Italy.

Foote, R. (Capt.) 1929. Letter from Capt. Foote to the Honourable Colonial Secretary, Belize, British Honduras. Belize Archives Department, Belmopan, Belize.

Gibson, J., M. McField, and S. M. Wells. 1998. Coral reef management in Belize: an approach through Integrated Coastal Zone Management. Ocean and Coastal Management 39:229-244.

Glaholt, R. D., and J. Seeb. 1992. Preliminary investigation into the origin of the spiny lobster, Panularia argus (LATREILLE, 1804) population of Belize, Central America (Decapoda, Palinuridea). Crustaceana 62:159-165.

Gordon, E. T. 1986. The impact of the cooperative on the emergence of the lobster industry in San Pedro, Belize. Belcast Journal of Belizean Affairs 3:15-30.

Government of Belize. 2000. Ministry of Agriculture Fisheries and Cooperative: historical year for Placencia Producers' Cooperative. Government of Belize Press Office, Belize.

Government of Belize. 2001. NEMO continues relief efforts. Government of Belize Press Office, Belize.

Grima, A., and F. Berkes. 1989. Natural resources: access, rights to use and management. Pages 33-54 in $\mathrm{F}$. Berkes, editor. Common property resources. Ecology and community-based sustainable development. Belhaven Press, London, UK.

Gunderson, L. H. 2003. Adaptive dancing: interactions between social resilience and ecological crises. Pages 33-52 in F. Berkes, C. Folke, and J. Colding, editors. Navigating socialecological systems. Building resilience for complexity and change. Cambridge University Press, Cambridge, UK.

Gunderson, L. H., C. S. Holling, and S. S. Light. 1995a. Barriers and bridges to the renewal of ecosystems and institutions. Columbia University Press, New York, New York, USA.

Gunderson, L. H., S. S. Light, and C. S. Holling. 1995b. Lessons from the Everglades. Learning in a turbulent system. BioScience 45:S66-S73.

Heyman, W. D., and R. Graham. 2000. The voice of the fishermen of Southern Belize. TIDE 
TRIGOH, Punta Gorda, Belize.

Heyman, W. D., and B. Kjerfve. 1999. Hydrological and oceanographic considerations for integrated coastal zone management in southern Belize. Environmental Management 24:229-245.

Holling, C. S. 1986. The resilience of terrestrial ecosystems: local surprise and global change. Pages 342-362 in W. Clark and R. Munn, editors. Sustainable development of the biosphere. Cambridge University Press, Cambridge, UK.

Holling, C. S., L. H. Gunderson, and D. Ludwig. 2002. In quest of a theory of adaptive change. Pages 3-22 in L. H. Gunderson and C. S. Holling, editors. Panarchy. Understanding transformations in human and natural systems. Island Press, Washington, D.C., USA.

Holling, C. S., and G. K. Meffe. 1996. Command and control and the pathology of natural resource management. Conservation Biology 10:328-337.

Hughes, T. P. 1994. Catastrophes, phase shifts, and large-scale degradation of a Caribbean coral reef. Science 265:1547-1551.

Huitric, M., C. Folke, and N. Kautsky. 2002. Development and government policies of the shrimp farming industry in Thailand in relation to mangrove ecosystems. Ecological Economics 40:441-455.

Jacobs, N. 1999. Assessment of marine and fisheries resources in the southern region of Belize. Environmental and social technical assistance project. ESTAP - IDB Project No. 999/OC-BL, Caracol Consultants International Ltd., Belmopan, Belize.

Johannes, R. E. 1998. The case for data-less marine resource management: examples from tropical nearshore finfisheries. Trends in Ecology and Evolution 13:243-256.

Johannes, R. E. 2002. The renaissance of community-based marine resource management in Oceania. Annual Review of Ecology and Systematics 33:317-340.

Joyce, I. 1997. The spiny lobster fishery in Cuba. Geographical Review 87:484-104.
Jury, S., H. Howell, D. O' Grady, and W. Watson, III. 2001. Lobster trap video: in situ video surveillance of the behaviour of Homarus americanus in and around traps. Marine and Freshwater Research 52:1125-1132.

King, T. 1997. Folk management among Belizean lobster fishermen: success and resilience or decline and depletion? Human Organization 56:418-426.

Kvale, S. 1996. InterViews. An introduction to qualitative research interviewing. Sage Publications, London, UK.

Ludwig, D., R. Hilborn, and C. Walters. 1993. Uncertainty, resource exploitation, and conservation: lessons from history. Science 260:17-36.

McCay, B., and J. Acheson, editors. 1987. The question of the commons. The culture and ecology of communal resources. The University of Arizona Press, Tucson, Arizona, USA.

McField, M. D. 2000. Evaluation of management effectiveness. Belize marine protected areas system. Prepared for Coastal Zone Management Authority and Institute, Belize City, Belize.

McField, M., S. M. Wells, and J. Gibson, editors. 1996. State of the Costal Zone Report. Belize 1995. Coastal Zone Management Programme, Government of Belize, Belize City, Belize.

McManus, J. W. 1988. Coral reefs of the ASEAN region: status and management. Ambio 17:189-193.

Morgan, G. 1980. Population dynamics of spiny lobsters. Pages 189-217 in J. S. Cobb and B. Phillips, editors. The biology and management of lobsters. Academic Press, London, UK.

Morris, D. 1883. The colony of British Honduras. Its resources and prospects; with particular reference to its indigenous plants and economic productions. Harrison \& Sons, London, UK.

Mumby, P. J. 1999. Bleaching and hurricane disturbances to populations of coral recruits in Belize. Marine Ecology Progress Series 190:27-35.

Myers, N., and J. Kent. 1998. Perverse subsidies. Tax \$s undercutting our economies and environments alike. The International Institute for Sustainable Development, Winnipeg, Manitoba, 
Canada.

Olsson, P., and C. Folke. 2001. Local ecological knowledge and institutional dynamics for ecosystem management: a study of Lake Racken watershed, Sweden. Ecosystems 4:85-104.

Ostrom, E. 1990. Governing the commons. The evolution of institutions for collective action. Cambridge University Press, Cambridge, UK.

Ostrom, E., J. Burger, C. Field, R. Norgaard, and D. Policansky. 1999. Revisiting the commons: local lessons, global challenges. Science 284:278-284.

Ostrom, E., R. Gardner, and J. Walker. 1994. Rules, games, and common-pool resources. University of Michigan Press, Ann Arbor, Michigan, USA.

Pauly, D. 1995. Anecdotes and the shifting baseline syndrome of fisheries. Trends in Ecology and Evolution 10:430.

Pinto, S., and H. Vasquez. 1989. Belize C.A. A profile of its fishing industry. Belize Fishermen Cooperative Association, Belize City, Belize.

Redman, C. 1999. Human impact on ancient environments. University of Arizona Press, Tucson, Arizona, USA.

Regier, H., and G. Baskerville. 1986. Sustainable redevelopment of regional ecosystems degraded by exploitive development. Pages 75-101 in W. Clark and R. Munn, editors. Sustainable development of the biosphere. Cambridge University Press, Cambridge, UK.

Roodman, D. 1996. Paying the piper: subsidies, politics, and the environment. Worldwatch Paper 133. Washington, D.C., USA.

Ruddle, K., E. Hviding, and R. E.Johannes. 1992. Marine resources management in the context of customary tenure. Marine Resource Economics 7:249-273.

Seixas, C., and F. Berkes. 2003. Dynamics of social-ecological changes in a lagoon fishery in southern Brazil. Pages 271-298 in F. Berkes, C. Folke, and J. Colding, editors. Navigating socialecological systems. Building resilience for complexity and change. Cambridge University
Press, Cambridge, UK.

Silberman, J., S. Sarver, and P. Walsh. 1994. Mitochondrial DNA variation and population structure in the spiny lobster Panulirus argus. Marine Biology 120:601-608.

Smith, A., and F. Berkes. 1991. Solutions to the "Tragedy of the Commons": sea-urchin management in St. Lucia, West Indies. Environmental Conservation 18:131-136.

Smith, A., and F. Berkes. 1993. Community-based use of mangrove resources in St. Lucia. International Journal of Environmental Studies 43:123-131.

Stoner, A. 1997. The status of queen conch, Strombus gigas, research in the Caribbean. Marine Fisheries Review 59:14-23.

Sutherland, A. 1986. Caye Caulker. Economic success in a Belizean fishing village. Westview Press, Boulder, Colorado, USA.

Thompson, E. 1944. The fisheries of British Honduras Report. Development and welfare in the West Indies. Bulletin No. 21.

van der Leeuw, S. E., and A. R. Team. 2000. Land degradation as a socionatural process. Pages 357383 in R. J. McIntosh, J. A. Tainter, and S. K. McIntosh, editors. The way the wind blows: climate, history, and human action. Columbia University Press, New York, New York, USA.

Wilk, R. 1999. "Real Belizean food": building local identity in the transnational Caribbean. American Anthropologist 101:244-255. 


\section{APPENDIX 1. a) Fishing Vessels and b) Fishing Gear Used in Belize for Lobster and Conch}

\begin{tabular}{lll}
\hline \hline Target Description Distribution & Den \\
\hline
\end{tabular}

a) Fishing Vessels

Dorey

Sailing smack

Skiff

b) Fishing Gear

Bully nets

Heart Weirs

Lobster trap - north
Dugout canoe poled in shallow waters or paddled, aided with a sail. Ideal along the coast and in shallow mangroves, but not very stable in open seas or rough weather. Dorey production rare now because fishermen invest in larger boats and the large trees needed are rare (Mr. Bobby, personal communication).

Sailboat (around $7 \mathrm{~m}$ long) with livewell (hold in center of boat that fills with seawater to keep catch alive). Eventually replaced by a drywell, filled with seawater, and later ice. The crew (8-12) load the boat with ice and dories in Belize City. On the fishing grounds, the boat is anchored and the crew paddle from the ship in their dories to fish. They then lift anchor and move to the next stop.

With outboard engines.

Lobster adults on

Placing the looking glass, an open box with a glass bottom, over side of the boat reef, Conch to observe seabed. When catch spotted, the net, a pole with a small net on the end, was used to catch the lobster. Restricted to shallower waters on the reef and patch reefs.

Lobster

Made of chicken wire held up by poles. Stretched perpendicular from shore (about $10 \mathrm{~m}$ ) and curved into a half circle at the end. Checked daily.

Lobster - In shallow, clear waters on sand patches in San Pedro, Caye Caulker, migrating ju- seagrass beds. Two men are needed to haul Belize City. Used in the veniles and traps: one to navigate and haul traps, and young adults one to man the boat. Not baited, as lobster are attracted to trap for shelter. Traps are not marked to prevent poaching; fishermen use triangulation to memorize trap placement. Check traps every 7 days.

Based on the Canadian lobster trap.

Trapezoidal for stability. Made of (palmetto) wood slats, built and repaired in the closed season.
Nationally until the early 1900s. Still used today in the Toledo district.

Today: Sarteneja. Past: Nationally, although few south of Dangriga

Nationally. Fewer in the very north and south.

Nationally

Nationally main lagoon and Turneffe Atoll lagoon. 
Lobster trap - south

Casitas and shades

Skin diving, masks and fins

Gillnet
Lobster - $\quad$ Rectangular wire cage. Set at 10-30 m. adults on Traps are baited to attract lobster in the reef, migrating deeper waters with reduced visibility. juveniles and young adults

Lobster - Square sheets of corrugated iron or cement Northern Belize migrating ju- are set over four stumps sunk in the sand veniles and to provide a shelter that attracts migrating young adults lobster. These are checked regularly. No damage, as lobster are free to wander at all times.

Lobster - $\quad$ Fishermen use a stick with a claw-like adults on hook on the end to pull lobster from den. reef, Conch Catch is often maimed or killed. Dive for

Punta Negra, Monkey River,

\section{Placencia}

Lobster - Gillnets were introduced in Punta Gorda in Southern Belize migrating ju- 1960 s by a Guatemalan resident. Used veniles and over seagrass beds.

young adults conch over seagrass bed.

Nationally 


\section{APPENDIX 2. History of the Development of the Lobster and Conch Fisheries in Belize}

Belize was claimed by the Spanish in the $16^{\text {th }}$ century and seized by the British in 1798 , becoming British Honduras in 1862 (Bolland 1997). In 1973, the colony's name was changed from British Honduras to Belize; Belize gained independence on 21 September 1981. I have chosen to refer to Belize and Belize City, formerly British Honduras and Belize respectively, throughout the paper.

The British used the colony to export logwood, hardwood, and sugar. Because of the constant shortage of labor, as it was a sparsely populated coastline, colonists imported slaves to work on the plantations (Bolland 1997). The colony also imported many basic goods, including fish products, and continues to depend on these imports (Wilk 1999).

Fishing was limited to a few fishers allowed to fish in the vicinity of Belize City (Daly Price 1986). There were few markets for fish in the colony, which limited the number of people who could make a living from fishing (Gordon 1986). Until the early 1900s, independent fishing was restricted to two groups, the Garifuna in the south and the Mestizos in the north, who immigrated to Belize in the early $19^{\text {th }}$ century and lived relatively isolated from the rest of the colony (Craig 1966). The Garifuna came from the Caribbean island of St. Vincent. In 1635, two ships carrying slaves from Nigeria shipwrecked on the island. The Nigerians settled and inter-mixed with the indigenous Arawak as free men. By 1773, the majority of the people on the island belonged to what was called the Garifuna. The British colonists wanted to regain control of this group and after much warring, deported the Garifuna to Roatan Island. From here, they gradually migrated to the mainland, and are reported to have arrived in Belize in the early 1800s. During the Caste War in the Yucatan (1847-1855), Belize agreed to accept refugees from this area. The colonial government classified these refugees, who were in fact a mixture of Spaniards, Indians, and Mestizos, as Mestizos; in time, they did indeed mix. These immigrants settled in northern Belize.

The main targets were fish and turtle, which were fished from dories with hand lines, harpoons, nets, traps, and weirs (Daly Price 1986, App. 1). At the end of the 1800s, conch meat was consumed in small quantities (Morris 1883), and according to newspapers at the time, there were canneries processing lobster, conch, and crabmeat (R. Wilk, personal communication, 2003). This was probably not in large quantities, as lobster was "eaten by the poor because it was abundant, by the elite because it was rare in Europe, but shunned by the middleclass as a "trash fish"" (Wilk 1999). In the early $20^{\text {th }}$ century, prices for timber and sugar began to drop, increasing the unemployed workforce in the colony (Gordon 1986). In the early 1900s, foreigners saw an opportunity to market spiny lobster as a substitute for the North American lobster (Gordon 1986), whose yield was in decline (Acheson 1988).

\section{5-1960: Introduction of Lobster as a Commodity}

In 1915, Mr. Stibbs, an American visiting San Pedro, introduced bully nets (App. 1) to local fishers for lobster fishing, and began exportiing lobster to the USA (Daly Price 1986). In 1923, Capt. Foote, a Canadian, introduced the lobster trap (App. 1) to fishers from Belize City; he set up a barge with a cannery off the southern end of Water Caye (Fig. 1) to export lobster to the USA (Daly Price 1986). The catch is reported to have declined after a few months (Daly Price 1986), and the operation closed in 1925 because of labor disputes, as fishers were aware that they could get higher prices in the Honduras (Craig 1966, Gordon 1986). Foote relocated his barge to Caye Caulker and then to Turneffe Atoll in 1929 (Capt. Foote 1929), where it was destroyed by the 1931 hurricane (Figs. 1, 4).

Foote relocated to Caye Caulker in 1932 with a new barge, where he trained local fishers to use the traps. These fishers dominated the lobster industry until recently. The industry closed down in the early 1930s because of an unsettled market in the USA, but picked up again during the 1940s (Craig 1966, Figs. 3, 4). The First World War introduced refrigerated vessels to the fisheries. These came periodically from the USA to collect catch from Placencia, Belize City, and Caye Caulker, and to take fishers to the atolls (Daly Price 1986). Fishers in the north and some from Belize City used traps. Bully nets and weirs (App. 1) were 
used on and near the reef, where traps could not be used, or when fishers had to travel long distances.

In the 1950s, processing and freezing facilities were established in Belize City allowing year-round fishing and processing of lobster (Daly Price 1986, Fig. 4). By the early 1950s, the lobster industry was considered an established industry by the government and export duties were established. Exporters were in heavy competition for supply, and price wars were common (Bradley 1956). Despite this, the maximum price paid to fishers per pound of lobster tail was $15 \mathrm{BZ}$ cents (Gordon 1986). In the 1950s, the national catch stabilized and declined for the first time (Fig. 3). Until the 1950s, fishers from San Pedro caught lobster within a day's journey of the village, and catches of 300-400 lobsters within a mile of the island were common (Gordon 1986). In 1953, fishers could collect 100-200 lobsters per day with bully nets. By 1955, bully nets were abandoned because they were no longer profitable (Daly Price 1986). San Pedro's fishing grounds had stretched from the southern tip of Ambergris Caye to the northern tip of Caye Caulker and from the reef to Cayo Congrejo (Fig. 1), but they now needed to travel further (Gordon 1986). By the 1950s, trap fishers in the north had established informal territories in trappable grounds, a system that persists today (King 1997). By 1957, the northern lagoon and Turneffe Atoll's lagoon were fully claimed (Fig. 4), displacing fishers that had been using bully nets, and resulting in conflict (Daly Price 1986).

Art Pinder, an American, introduced masks, fins, and the hook (App. 1) to fishers in San Pedro in 1957 (Daly Price 1986). This allowed fishers to skin dive for lobster on the reef, which is not accessible to traps. Skin diving was more efficient than bully nets, and eliminated the issue of limited entry. It also allowed fishers to travel to more distant fishing grounds, which was inconvenient with bulky traps. This required bigger boats, ice, and iceboxes. Outboard engines and improved access to ice assisted the spread of fishers and the intensification of trapping, as more traps could be checked per day. Fishers began to travel more regularly to the comparatively unexploited atolls. Catches on the atolls were so large, over $220 \mathrm{~kg}$ of tails per day, that fishers began to land only tails, as these fetched a better price than whole lobster (Gordon 1986).

1960-mid1980s: Development and Growth of the Cooperatives

Fishers were aware that proceeds from sales abroad were not fairly distributed, but lacked the capital needed to process, market, and export the catch (Bradley 1956). In 1960, 39 fishers from Caye Caulker came together to form the Northern Fishermen's Cooperative Society (Sutherland 1986). Although its members were from Caye Caulker, the cooperative was established in Belize City to be near the harbor and airport, and receiving stations were built in both Belize City and Caye Caulker. In 1962, fishers in Placencia formed the Placencia Producers' Cooperative Society, and in 1963, fishers of San Pedro formed the Caribeña Producers' Cooperative (Gordon 1986), both of which were located in their respective towns. In the mid-1960s, the National Fishermen Producers' Cooperative Society was established in Belize City. Many cooperatives were started in subsequent years. Most were short lived, but the four cooperatives named above have persisted (Belize Fisheries Department 2001).

In 1961, Hurricane Hattie disrupted fishing in Belize by destroying processing equipment in Belize City and fishing gear from the north to Belize City; this impacted the fishing grounds, including all of the atolls (Craig 1966). Accounts in Craig's (1966) work reported that Lighthouse Reef Atoll's grounds had not recovered 4 years later. Nevertheless, both processing and national lobster landings recovered within a year (Barclays Bank 1962, Fig. 3).

In 1960, the Northern Fishermen's Cooperative Society still depended on a foreign exporter, and paid its members $17 \mathrm{BZ}$ cents; this increased to 28 cents later that year-almost doubling, compared with the prices in the 1950s. By 1964, it had its own processing plant and paid its members $2.10 \mathrm{BZ} \$$ per pound lobster tail compared with the Caribeña Producers' Cooperative, which did not yet have a processing plant, and paid its members 1.04 BZ\$ (Gordon 1986). Fishers' incomes jumped by over $1000 \%$ in less than 5 years (Godfrey in Sutherland 1986). In 1965, the Government of Belize passed a law that only cooperatives would be granted export quotas (Daly Price 1986). This shut down all foreign exporters and ensured that the revenues from the export of marine products remained in Belize. 
In 1965, the Caribeña Producers' Cooperative was the largest cooperative in Belize, with 152 members; it was the first to diversify, exporting lobster, conch, and fish. Conch was abundant, easy to fish, and had good export prices, which led to a boom in its landings that peaked in 1975 (Fig. 3). Cooperative board members from Belize City and Placencia explained that "you did not fish for conch!" You rolled up your trousers and waded from shore to collect conch. Despite the low pay, you could make a living because of its abundance. Later, the looking glass and eventually skin diving were needed to fish the deeper conch. By the early 1970s, the first conch grounds were in decline (Baird 1973), and in the mid 1970s, conch landings plummeted and have never recovered (Fig. 3). Interviewees, commenting on the changes in conch, all agreed that the crash in production was a result of fishing, which is supported by earlier interview studies (Jacobs 1999, Heyman and Graham 2000). During interviews with fishers, many believed that the conch fishery should be closed for a while. Although the lobster yield stabilized in the mid-1980s (Fig. 3), good prices allowed displaced conch fishers to switch to lobster, and continued to attract new fishers. At the time, the average salary of a lobster fisher was five times above the average per capita income and twice the salary of civil servants (Central Statistical Office statistics in Daly Price 1986). In the 1980s, the cooperatives had 1000 members, $80 \%$ of who were dependent on lobster (Daly Price 1986).

The introduction of skiffs in the 1980s made all shallow grounds readily accessible to fishers throughout the country and allowed further trap intensification. Despite these improvements, by 1986, it was rare to catch more than $500 \mathrm{~kg}$ of lobster following a 10-day trip (Gordon 1986). In the 1940s, fishers had an average of 10-15 traps, which increased to around 100 traps per fisher with the advent of outboard engines (Daly Price 1986). According to the cooperative board members interviewed, trap fishers in the north of Belize have been the most productive fishers in Belize. However, they have also been increasing effort, although their catch has not grown. A cooperative board member reported that fishers can have up to 1200 traps, checking between 350 and 400 traps every 2 days. Another board member claimed that there are so many traps in the lagoon that no lobster can make it to the reef.

In the 1980s, gillnets (App. 1) were introduced in Monkey River (Fig. 1) to fish lobster. Two key informants from this area reported that these nets produced large yields, with 50-foot nets catching up to 150 lobsters. Both of these interviewees reported that this boom lasted for 2-3 years, and then stabilized despite continued investment in nets.

\section{Mid1980s-Present: Stabilized Production for the Cooperatives}

Since the 1980s, the national catch has been relatively stable (Fig. 3). Illegal fishing of under-sized and berried females was already reported in the 1970s (Baird 1973). During the interviews, almost all reported illegal fishing by foreigners and locals. This included taking undersized and berried lobster, as well as cross-border smuggling of catch out of season and when prices were higher in neighboring countries. In the south, there are problems with fishers from Guatemala and Honduras coming to fish in Belize's waters. There are no estimates on the amount of production this activity might account for.

Several of the cooperative board members interviewed commented on the change in the composition of fishers as the number of fishers has grown and traditional fishers have retired or left the industry. With increased incomes, fishers were able to pay for further schooling for their children, who have turned to other kinds of work (Gordon 1986, King 1997). Many fishers have switched to tourism, becoming tour guides, or selling their catch directly to the tourist industry. A cooperative board member explained that many young fishers were turning to tourism as this at least guaranteed a paycheck at the end of the day, which is not always the case with fishing. There was a feeling of disappointment among the cooperative board members with regard to the young membership, who they viewed as less loyal. They attributed this, in part, to their having been born into the cooperatives and never having needed to fight for them. 